\title{
COLLABORATION MODEL FOR COMMUNITY HEALTH WORKER EMPOWERMENT TO ENHANCE THE USE OF MATERNITY WAITING HOME
}

\author{
Arlina Dewi'), Supriyatiningsih²), Sri Sundari²), Dianita Sugiyo3) \\ 1)Masters Program in Hospital Management, Universitas Muhammadiyah Yogyakarta \\ 2) Study Program of Medical Education, Faculty of Medicine and Health Sciences, \\ Universitas Muhammadiyah Yogyakarta \\ 3) Study Program of Nursing, Faculty of Medicine and Health Sciences, \\ Universitas Muhammadiyah Yogyakarta
}

\begin{abstract}
Background: Maternal Mortality Rate (MMR) in Indonesia has increased from 2007 to 2015 as many as 228/100,000 live births to 305/100,000 live births. The government has made a policy to reduce MMR in rural and remote areas, including the maternity waiting home (MWH) program and the placement of village midwives. However, the use of MWH in Indonesia is still low, such as in South Sulawesi Province. This study aimed to determine the effect of community health worker (CHW) empowerment collaboration model to enhance the use of MWH.

Subjects and Method: This was a quasi-experimental study with pretest-posttest control group design. This study was located in 4 community health centers, Bulukumba, South Sulawesi. A total sample of 125 pregnant women was selected and divided into two groups consisting of 66 in the experimental group and 59 in the control group. The CHW empowerment collaboration model was carried out through 4 stages, namely CHW training, home visits for early pregnant women, collaboration of $\mathrm{CHW}$ with village midwives, and home visits for pregnant women. The control group did not get an intervention. The dependent variables were changes in the level of knowledge about pregnancy, attitude, and use of MWH. The data were collected by questionnaire. The data were analyzed by Spearman rank correlation and chi-square.

Results: There were statistically significant increases in knowledge, attitude, and the use of MWH in the experimental group, while there were no statistical significant increases in the control group.

Conclusion: Community health worker empowerment collaboration model is effective to enhance knowledge, attitude, and the use of maternity waiting home.
\end{abstract}

Keywords: knowledge, attitude, use, maternity waiting home

\section{Correspondence:}

Arlina Dewi. Master Program in Hospital Management, Universitas Muhammadiyah Yogyakarta. Jl. Brawijaya, Bantul 55183, Yogyakarta, Indonesia. Email: dewikoen@yahoo.com. Mobile: +628122972576.

The $6^{\text {th }}$ International Conference on Public Health

Best Western Premier Hotel, Solo, Indonesia, October 23-24, 2019 | 244 https://doi.org/10.26911/the6thicph.04.06 